\title{
Dysfunctional Plasminogen in Full-Term Newborn
}

\author{
A. ESTELLES, J. AZNAR, ${ }^{(46)}$ J. GILABERT, AND J. J. PARRILLA
}

Research Center, Departments of Clinical Pathologv and Obstetrics and Gynecologv, Ciudad Sanitaria "La Fe" Valencia. Spain

\section{Summary}

Full-term newborns (FTN) plasminogen was evaluated by different techniques (affinity chromatography, immunologic technique, casein method, and chromogenic substrate). The functional activity of the FTN plasminogen was about $50 \%$ of that of the adult. This suggests the possible existence of a functional anomaly of plasminogen in FTN.

FTN plasminogen aminoacids were studied, and, besides small qualitative anomalies, a decrease in amino acid residues per mole of protein and a different $\mathrm{N}$-terminal amino acid were detected.

\section{Speculation}

The existence of a functional anomaly in full-term newborns' plasminogen has been suggested. The possible role of this anomaly in the pathogenesis of the hemorraghic diseases of the neonate and in hyaline membrane disease is not known, thus, the identification of this anomaly could contribute to a better understanding of these diseases.

Functional anomalies of several proteins with coagulant activity, especially fibrinogen $(5,21,42)$ and prothrombin $(32,33)$, have been described in full-term newborns (FTN), but in the literature that we have reviewed, a functional anomaly of FTN plasminogen has not been described.

In this paper, FTN plasminogen was evaluated by different techniques (affinity chromatography, immunologic technique, casein method, and chromogenic substrate), and the existence of a functional anomaly in plasminogen was suggested.

\section{MATERIALS AND METHODS}

Blood samples of normal adults were collected from the cubital vein and from those of FTN (Apgar 9/10), born spontaneously with no application of analgesic-anesthesic agents, from the umbilical vein, $5 \mathrm{~min}$ after birth. The blood was anticoagulated with $3.8 \%$ sodium citrate $(1: 9, \mathrm{v} / \mathrm{v}$, anticoagulant:blood $)$. The samples were divided into two tubes; 250 Kallikrein inactivating units of trasylol per $\mathrm{ml}$ of blood were added to one of the tubes. The samples were kept in ice during all these procedures. The plasmas were obtained by centrifugation at $3000 \mathrm{rpm}$ for $15 \mathrm{~min}$ at $4^{\circ} \mathrm{C}$.

Reagents: Human plasminogen (Kabi; $25 \mathrm{CU} /$ vial); alpha casein (Sigma Chemical Co.), streptokinase (SK) (Behringwerke, $5,000 \mathrm{U} / \mathrm{vial}$; Kabi 250,000 U/vial); urokinase (UK) (Roger. 25,000 units/vial); antiplasminogen serum (Behringwerke); Sepharose 4B activated with cyanogen bromide (Pharmacia Fine Chemical); chromogenic substrate (Kabi, S-2251).

\section{EVALUATION OF PLASMATIC ANTIFIBRINOLYTIC ACTIVITY}

To evaluate plasmatic antifibrinolytic activity, the antiplasmins (chromogenic substrate) (37) and the antistreptokinases (18) were determined.

\section{EVALUATION AND PURIFICATION OF PLASMA PLASMINOGEN}

Plasminogen was assayed by the following techniques: hemaglutination inhibition method as proposed by $\mathrm{Wu}$ et al. (43) and modified by Estelles et al. (11) by using commercial plasminogen as the standard in each experiment; the casein method of Hedner and Nilsson (19), but using urokinase [neutralized plasma (55 units $/ \mathrm{ml}$ )] to activate plasminogen (a reference curve of a pool of normal plasmas was plotted every day); the chromogenic substrate (S-2251) method, in which the plasminogen was activated with an excess of SK, and under this condition, a SK-human plasminogen complex was performed, and the resulting enzymatic activity was not inhibited by plasmin inhibitors in plasma $(12,13)$; the affinity chromatography technique (9), in which columns of $0.8 \mathrm{~cm}$ internal diameter were packed with $5 \mathrm{ml}$ of L-lysine substituted Sepharose 4B activated with cyanogen bromide and to which $2 \mathrm{ml}$ of plasmas were added. Elution was performed with $\epsilon$-aminocaproic acid (EACA) $(0.2 \mathrm{M})$, and the plasminogen was obtained in the second peak of elution. Plasminogen quantification was performed spectrophotometrically using the extinction coefficient proposed by Zolton and Meitz (44); results were calculated as follows:

Plasminogen $(\mu \mathrm{g} / \mathrm{ml})$

$$
=\frac{\mathrm{A} 280-\mathrm{A} 320}{1.71} \times \frac{\mathrm{ml} \text { column eluate }}{\mathrm{ml} \text { plasma }} \times 1000
$$

The yield of this procedure was 85 to $95 \%$ using commercial plasminogen.

The homogeneity of the material obtained in the second peak was evaluated by electrophoresis in 5\% polyacrylamide gel in the presence of $0.1 \%$ sodium dodecyl sulphate (SDS) in a $0.1 \mathrm{M}$ phosphate ( $8 \mathrm{~mA} ; 2 \mathrm{hr})$ (34). Staining was accomplished with amino-black 10B. Identification of this material was carried out by the haemaglutination inhibition (43) and by the Ouchterlony techniques (25).

Several pools of adult, commercial, and FTN plasminogens were obtained by affinity chromatography and were subjected to repeated dialysis against phosphate buffer $(0.1 \mathrm{M} ; \mathrm{pH} 7.4)$ for 3 days at $4^{\circ} \mathrm{C}$ to eliminate the EACA. All pools were adjusted to a similar protein concentration.

\section{EVALUATION OF THE FUNCTIONAL ACTIVITY OF PURIFICATED PLASMINOGEN SAMPLES}

Casein method (19). One-tenth $\mathrm{ml}$ of SK (Behringwerke; 5000 units $/ \mathrm{ml})$ was added to $1 \mathrm{ml}$ of purified plasminogen $(52 \mu \mathrm{g} / \mathrm{ml})$ and incubated for $20 \mathrm{~min}$ at $37^{\circ} \mathrm{C}$. Then $2 \mathrm{ml}$ of $1 \% \alpha$-casein solution were added, and after $20 \mathrm{~min}$ at $37^{\circ} \mathrm{C}$, proteolysis was stopped by the addition of $1 \mathrm{ml}$ of trichloroacetic acid $(20 \%)$. Plasminogen concentration was expressed in caseinolytic units (defined in such a way that 10 caseinolytic units gave an absorbance of 0.300 ).

The same procedure was carried out using UK as an activator [ $(0.1 \mathrm{ml} \mathrm{UK}(500$ units $/ \mathrm{ml})] / 1 \mathrm{ml}$ of purified plasminogen solution (50 to $60 \mu \mathrm{g} / \mathrm{ml}$ ). 
Chromogenic substrate. One-tenth $\mathrm{ml} \mathrm{UK} \mathrm{(100} \mathrm{units/ml)} \mathrm{was}$ added to $0.2 \mathrm{ml}$ of purified plasminogen solution $(50$ to $60 \mu \mathrm{g}$ / $\mathrm{ml})$. The last part of this technique was made after Friberger $\boldsymbol{e t}$ al. $(12,13)$. The results were calculated from a standard curve prepared from adult plasminogen solution ( 20 to $60 \mu \mathrm{g} / \mathrm{ml}$ ).

\section{STUDY OF THE N-TERMINAL. AMINO ACIDS OF PURIFIED PLASMINOGEN}

$N$-Terminal plasminogen amino acids were identified by dansylation after Gros and Labounesse (15). The dansylamino acids were identified by thin-layer chromatography on polyamide sheets (BDH Chemicals, Ltd); ammonia: acetone (1:100 v/v), anf formic acid:butanol: $n$-heptane $(1: 10: 10 \mathrm{v} / \mathrm{v} / \mathrm{v})$ were used as solvents.

\section{KINETIC ACTIVATION STUDIES OF PURIFIED PLASMINOGEN}

The adult and FTN plasminogen $(500 \mu \mathrm{g} / \mathrm{ml})$ were treated with catalytic SK (Kabi PG/SK 100:1 on a molar basis) (22). Samples of $100 \mu \mathrm{l}$ were removed from the digestion mixture at 5,20 , and $60 \mathrm{~min}$, and $10 \mu \mathrm{l}$ of $\beta$-mercaptoethanol were added; the mixture was left for $20 \mathrm{~min}$ at $90^{\circ} \mathrm{C}$. The samples were evaluated by electrophoresis in 5\% polyacrylamide gel with SDS as described previously. The molecular weights were estimated by comparison to a standard curve which was obtained by plotting the $\log$ of the molecular weights (between 340,000 and 25,000). The gels were scanned, and the bands were integrated with a densitometer. An internal standard was used to estimate protein recovery.

\section{STUDY OF AMINO ACID COMPOSITION}

To evaluate the emino acid composition of the plasminogen samples, the materials were concentrated and hydrolyzed under vaccum with $6 \mathrm{~N} \mathrm{HCl}$ at $110^{\circ} \mathrm{C}$ for $18 \mathrm{hr}$. Amino acid analyses were performed using a Beckman amino acid analyzer, Multicrom B model, with a column of $60 \times 0.9 \mathrm{~cm}$, packed with type M-82 resin. Norleucine was used as an internal standard. The residues were calculated as mole of amino acid per mole of plasminogen (29).

\section{RESULTS}

STUDY OF THE FIBRINOLYSIS INHIBITORS IN FTN

Antiplasmin activity (chromogenic substrate method) was $98.5 \%$ \pm 15.36 in the adult plasma and $70.4 \pm 29.1$ in FTN plasma. The percentage of the inhibitors of plasminogen activation by streptokinase was $94.66 \% \pm 31.4$ in FTN plasma (adult 100\%).

\section{FUNCTIONAL ACTIVITY OF FTN PLASMINOGEN}

The plasminogen in adults and FTN was evaluated by affinity chromatography and by an immunologic method. The resulting plasmin was assayed by the casein method (urokinase was used as the activator) and by the chromogenic substrate method (streptokinase was used as the activator). Considering adult activity as $100 \%$, FTN plasminogen protein level was $47.3 \%$ (immunologic method) and $46.6 \%$ (affinity chromatography), and FTN functional plasminogen activity was only $27.1 \%$ (casein method) and $27.3 \%$ (chromogenic substrate) (Table 1).

\section{PLASMINOGEN PURIFICATION AND CHARACTERIZATION}

Using affinity chromatography, two protein peaks were obtained from adult and FTN native plasma, the first with phosphate buffer (0.3 M: $\mathrm{pH} 7.4)$, and the second with phosphate buffer $(0.1$ M EACA (0.2 M; pH 7.4). In evaluating adult, FTN, and commercial plasminogen eluates (immunologic method), plasminogen was observed only in the second peak. Homogeneity of adult FTN and commercial plasminogen was confirmed SDS [polyacrylamide gel electrophoresis (5\%)] (Fig. 1). A component with a lower molecular weight than that of plasminogen was observed in reduced FTN plasminogen samples (Fig. 2).

The three plasminogens showed a reaction of complete identity against antiplasminogen rabbit serum (Fig. 3 ).

To evaluate the functional activity of plasminogen per $\mathrm{mg}$ of protein, three pools $(52 \mu \mathrm{g} / \mathrm{ml})$ obtained by affinity chromatography from adult, FTN, and commercial plasminogens were prepared. In these pools, the functional activity (casein method, using streptokinase as the activator) per $\mathrm{mg}$ of protein (affinity chromatography) was evaluated on 3 consecutive days. FTN plasminogen functional activity was $34 \%$ of that of the adult and $44.3 \%$ of that of commercial plasminogen (Table 2).

Adult and FTN plasminogen functional activity was evaluated in other pools by the chromogenic substrate and casein methods (urokinase was used as the plasminogen activator). FTN plasminogen activity was $45.3 \%$ (chromogenic substrate) and $30 \%$ (casein method) compared with that of the adult.

Unactivated purified plasminogen samples showed no plasmin activity (chromogenic substrate).

Glutamic acid with traces of valine and lysine were the $\mathrm{N}$ terminal amino acid residues found for the adult and commercial plasminogen, whereas valine and lysine were the most frequent $N$-terminal amino acid residues of the FTN plasminogen and only traces of glutamic acid were observed (Table 3).

Finally, the amino acid composition of the three pools of plasminogen (adult, commercial, and FTN) was evaluated. Table 4 shows that in the FTN plasminogen there exist no notable differences in the proportions of amino acids in relation to the commercial and adult plasminogens. However, a relative increase in glycine and phenyl alanine and a decrease in the amino acid residues per mole of plasminogen were observed.

\section{CATALYTIC ACTIVATION OF PLASMINOGEN WITH STREPTOKINASE}

Adult and FTN plasminogens were treated with catalytic streptokinase. Samples were removed from the digestion mixture at the times indicated and treated as described in "Materials and Methods." The quantitative scan data are shown in Table 5. A rapid increase in plasminogen fragments $64,000,54,000,25,000$, and 14,000 was observed.

To identify the activation components produced during the activation of adult and FTN plasminogens, similar activation of commercial plasminogen with streptokinase was performed (Figs. 4 and 5), and activation components similar to that of adult and FTN plasminogens were obtained. Figure 5 shows a rapid loss of plasminogen (PG-92) and the appearance of P1-64 and P1-25 fragments; these componerts are probably similar to the heavy and light chains of plasmin (14). In addition, there appears to be

Table 1. Evaluation of plasminogen in adults and FTN by different techniques

\begin{tabular}{|c|c|c|c|c|c|c|c|c|}
\hline & \multicolumn{8}{|c|}{ Plasminogen } \\
\hline & \multicolumn{2}{|c|}{$\begin{array}{l}\text { Affinity chromatography } \\
\qquad(\mu \mathrm{g} / \mathrm{ml})\end{array}$} & \multicolumn{2}{|c|}{$\begin{array}{l}\text { Immunologic method } \\
\qquad(\mu \mathrm{g} / \mathrm{ml})\end{array}$} & \multicolumn{2}{|c|}{$\begin{array}{c}\text { Casein method } \\
(\%)\end{array}$} & \multicolumn{2}{|c|}{$\begin{array}{c}\text { Chromogenic substrate } \\
(\%)\end{array}$} \\
\hline & FTN & Adult & FTN & Adult & FTN & Adult & FTN & Adult \\
\hline$\overline{\mathrm{X}}$ & 67.78 & 145.39 & 86.26 & 182.31 & 27.3 & 100.7 & 27.25 & 99.8 \\
\hline S.D. & 18.65 & 31.04 & 35.30 & 36.76 & 14.5 & 19.5 & 14.75 & 9.9 \\
\hline$n$ & 42 & 56 & 42 & 59 & 20 & 20 & 20 & 20 \\
\hline
\end{tabular}




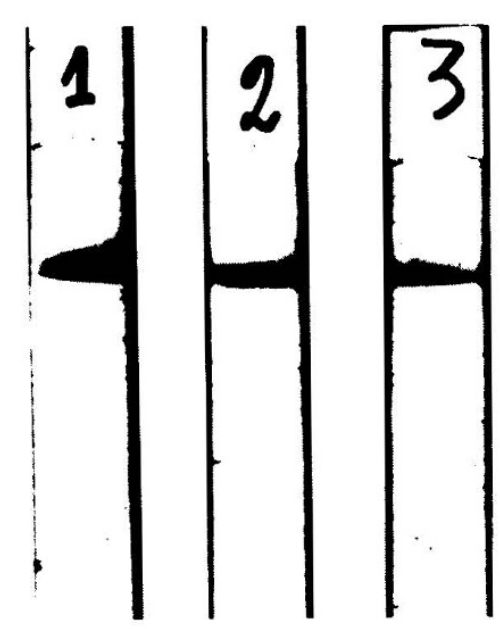

Fig. 1. Electrophoresis in 5\% polyacrylamide gel in the presence of $0.1 \%$ SDS of a sample of plasminogen obtained by affinity chromatography with L-lysine-substituted Sepharose activated with cyanogen bromide. I, Adult: 2, FTN; 3, commercial.

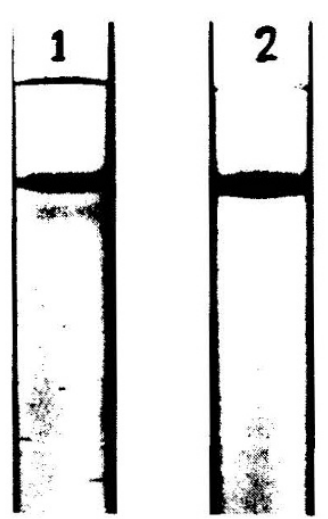

Fig. 2. Electrophoresis in $5 \%$ polyacrylamide gel in the presence of $0.1 \%$ SDS of a sample of plasminogen reduced by $\beta$-mercaptoetanol. $I$, FTN: 2, adult.

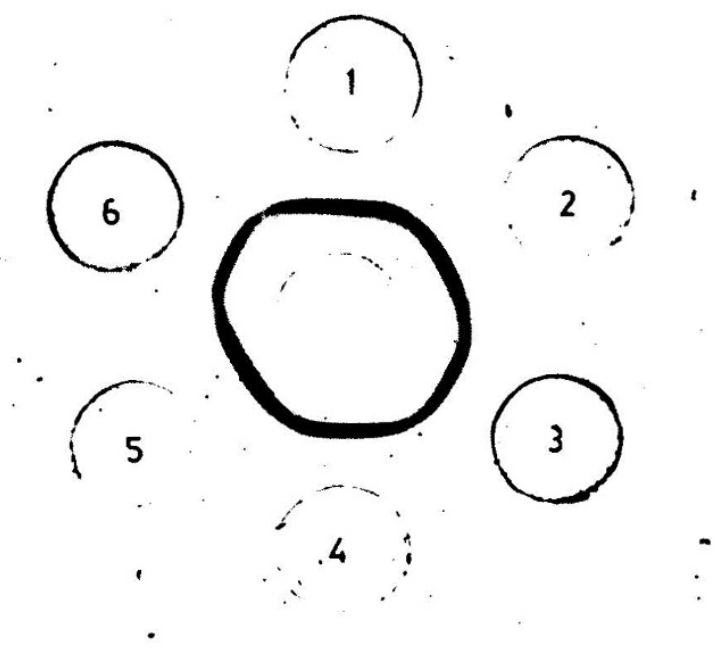

Fig. 3. Double immunodiffusion in agar of a sample of plasminogen Wells 1 and 4, commercial; wells 2 and 5, adult: wells 3 and 6, FTN: central well, antiplasminogen rabbit serum.
Table 2. Evaluation of the biologic activity of plasminogen per $\mathrm{mg}$ of protein of three pools of plasminogen obtained from adults, FTN, and commercial (all pools of the same protein concentration)

Plasminogen biologic activity ( $\mathrm{ACU}^{1} / \mathrm{mg}$ protein)

\begin{tabular}{cccc}
\hline Experience & Adult & FTN & Commercial \\
\hline 1 & 33.60 & 12.54 & 28.50 \\
2 & 30.65 & 7.63 & 20.84 \\
3 & 24.53 & 10.13 & 19.00 \\
& & & \\
$\bar{X}$ & 29.59 & 10.1 & 22.78 \\
S.D. & 4.63 & 2.45 & 5.03 \\
\hline
\end{tabular}

'ACU, arbitrary casein units.

Table 3. Study of the NH-terminal residue of the adult, commercial, and FTN plasminogen

\begin{tabular}{llll}
\hline \multicolumn{1}{c}{ Plasminogen } & Pool & $\begin{array}{c}\mu \mathrm{g} / \\
\mathrm{mI}\end{array}$ & \multicolumn{1}{c}{$\mathrm{NH}_{2}$-terminal residu } \\
\hline Commercial & & & \\
& I & 210 & Glu \\
& II & 225 & Glu \\
& III & 195 & Glu, Lys (trace) \\
& IV & 222 & Glu, Val (trace), Lys (trace)
\end{tabular}

Adult

$\begin{array}{lrl}\text { I } & 191 & \text { Glu, Val (trace), Lys (trace) } \\ \text { II } & 188 & \text { Glu, Val (trace), Lys (trace) } \\ \text { III } & 166 & \text { Glu, Val (trace), Lys (trace) } \\ \text { IV } & 150 & \text { Glu, Lys (trace) } \\ \text { V } & 95 & \text { Glu }\end{array}$

FTN

$\begin{array}{lrl}\text { I } & 35 & \text { Val, Lys (trace) } \\ \text { II } & 47 & \text { Val, Lys (trace) } \\ \text { III } & 50 & \text { Val, Lys (trace), Glu (trace) } \\ \text { IV } & 100 & \text { Val, Lys, Glu (trace) }\end{array}$

a conversion of P 1-64 into a smaller molecule of molecular weight of about 54,000, which agrees with previous reports $(14,22)$. Another fragment of molecular weight of about 14,000 also appears; this could be a degradation fragment of the light chain of plasmin, or it could be another unidentified activation peptide.

\section{DISCUSSION}

FTN hemostasis alterations have been known for some time. Although these alterations are widespread $(5,8,20,21,23,32,33$, $38,40,42)$, they especially affect the plasma factors synthesized in the liver $(4,16,17)$. It is known that the plasminogen level decreases in FTN $(1,10)$ and in premature newborns $(2,24,27)$. Although an anomaly in the plasminogen function has been described in adults (3), in the literature that we have reviewed only Potron et al. (26) suggest the existence of an abnormal-fetal plasminogen, but they do not prove its existence.

In our experiments, we have found a smaller amount of and less functional activity in the FTN plasminogen than in the adult plasminogen. We have also observed in the FTN plasminogen a different $N$-terminal amino acid, similar molecular weight evaluated by SDS polyacrylamide gel, similar kinetic activation evaluated by streptokinase; small, but notable qualitative differences in the amino acid composition, a smaller amount of amino acid residues per mole of plasminogen; and a different reduced SDS electrophoretic pattern of the plasminogen without activation. These results suggest qualitative and quantitative differences between the adult and FTN plasminogens that could be studied in depth. 
DYSFUNCTIONAL PLASMINOGEN IN FULL-TERM INFANTS

Table 4. Study of the composition of amino acids of FTN plasminogen compared with the adult and commercial plasminogen and with the results obtained by other authors

\begin{tabular}{|c|c|c|c|c|c|c|c|c|c|}
\hline & \multicolumn{2}{|c|}{$\begin{array}{l}\text { Robbins and Summaria } \\
\qquad(30)\end{array}$} & \multirow{2}{*}{$\begin{array}{l}\text { Robbins } \\
\text { et al. }(29) \\
\text { Lys-PG }\end{array}$} & \multirow{2}{*}{$\begin{array}{c}\text { McClintock } \\
\text { et al. }(22) \\
\text { Glu-PG }\end{array}$} & \multirow{2}{*}{$\begin{array}{c}\text { Wiman and } \\
\text { Wallen (41) } \\
\text { Glu-PG }\end{array}$} & \multirow{2}{*}{$\begin{array}{c}\text { Robbins and } \\
\text { Summaria (31) } \\
\text { plasmin }\end{array}$} & \multicolumn{3}{|c|}{ Our results } \\
\hline & Glu-PG ${ }^{1}$ & Lys-PG & & & & & Adult & Commercial & FTN \\
\hline Lys & 40 & 39 & 41 & 46 & 50 & 38 & 51 & 44 & 36 \\
\hline $\mathrm{His}$ & 21 & 21 & 21 & 22 & 22 & 21 & 20 & 24 & 20 \\
\hline Arg & 38 & 36 & 37 & 40 & 39 & 36 & 37 & 41 & 21 \\
\hline Asp & 72 & 67 & 71 & 72 & 76 & 60 & 61 & 65 & 38 \\
\hline Thr & 60 & 57 & 54 & 65 & 57 & 50 & 60 & 61 & 38 \\
\hline Ser & 57 & 48 & 44 & 56 & 51 & 40 & 66 & 62 & 48 \\
\hline Glu & 81 & 69 & 69 & 88 & 92 & 59 & 86 & 87 & 72 \\
\hline Pro & 68 & 66 & 65 & 54 & 73 & 61 & 55 & 60 & 32 \\
\hline Gly & 60 & 59 & 56 & 59 & 58 & 53 & 57 & 63 & 88 \\
\hline Ala & 38 & 33 & 32 & 37 & 38 & 29 & 41 & 35 & 43 \\
\hline Val & 44 & 41 & 43 & 40 & 44 & 36 & 33 & 31 & 29 \\
\hline Met & 8 & 8 & 9 & 10 & 8 & 8 & 9 & 13 & 10 \\
\hline I-Leu & 19 & 16 & 19 & 18 & 23 & 15 & 17 & 18 & 12 \\
\hline Leu & 40 & 40 & 40 & 41 & 43 & 36 & 40 & 41 & 31 \\
\hline Tyr & 27 & 29 & 29 & 28 & 28 & 26 & 23 & 31 & 36 \\
\hline Phe & 19 & 16 & 17 & 18 & 19 & 14 & 21 & 26 & 40 \\
\hline
\end{tabular}

${ }^{1}$ Glu-PG, $\mathrm{NH}_{2}$-terminal glutamic acid plasminogen; Lys-PG, $\mathrm{NH}_{2}$-terminal lysine plasminogen.

Table 5. Kinetic activation of adult and FTN plasminogen with catalytic streptokinase by using reduced SDS gel electrophoretic analysis

\begin{tabular}{|c|c|c|c|c|c|c|c|c|c|c|c|c|}
\hline \multirow{4}{*}{ Molecular wt } & \multicolumn{12}{|c|}{ Digestion time } \\
\hline & \multicolumn{4}{|c|}{$5 \mathrm{hr}$} & \multicolumn{4}{|c|}{$20 \mathrm{hr}$} & \multicolumn{4}{|c|}{$60 \mathrm{hr}$} \\
\hline & \multicolumn{2}{|c|}{ Adult } & \multicolumn{2}{|c|}{ FTN } & \multicolumn{2}{|c|}{ Adult } & \multicolumn{2}{|c|}{ FTN } & \multicolumn{2}{|c|}{ Adult } & \multicolumn{2}{|c|}{ FTN } \\
\hline & $\bar{x}$ & S.D. & $\mathrm{X}$ & S.D. & $\overline{\mathbf{x}}$ & S.D. & $\overline{\mathrm{X}}$ & S.D. & $\overline{\mathbf{x}}$ & S.D. & $\overline{\mathbf{x}}$ & S.D. \\
\hline 92,000 & 0 & 0 & 0.6 & 1.15 & 0 & 0 & 0 & 0 & 0 & 0 & 0 & 0 \\
\hline 64,000 & 88.5 & 21.9 & 90.33 & 11.5 & 86.5 & 10.3 & 87.3 & 6.5 & 74.25 & 16.5 & 78.33 & 2.08 \\
\hline 54,000 & 40.5 & 21.7 & 36.33 & 11.7 & 47.7 & 16.6 & 45 & 5.29 & 52 & 14.5 & 47.67 & 7.57 \\
\hline 25,000 & 29.7 & 12.4 & 43.33 & 17.95 & 26.5 & 11.1 & 36.67 & 18.14 & 28 & 20.2 & 33.5 & 21.9 \\
\hline 14,000 & 38.7 & 38 & 17.3 & 30 & 26.5 & 19.5 & 16 & 15.3 & 49.5 & 34.7 & 28 & 24.58 \\
\hline
\end{tabular}

${ }^{1}$ Numbers, number of moles of band per mole of plasminogen $\times 100$.

In our experiences, the functional activity per $\mathrm{mg}$ of protein of the FTN plasminogen was about $30 \%$ of that of the adult. These differences were detected in plasma and purified plasminogen by using both streptokinase and urokinase as the plasminogen activator.

The plasminogen hypofunction could not be attributed to an excess of fibrinolytic inhibitors in the FTN plasma because we have not found an increase in the antiplasmins and inhibitors of the streptokinase activation. Besides, in the casein method, the plasma is acidified to eliminate the fibrinolytic inhibitors, and in the chromogenic substrate method, the activity is not inhibited by plasmin inhibitors $(12,13)$. In addition, in the purified samples, in which the inhibitor is eliminated, anomalies in the FTN plasminogen were also detected.

It might be supposed that the hypofunction of the FTN plasminogen could be attributed to a technical deficiency in the purification process. However, because the FTN plasminogen has undergone a purification process identical to that of the adult and commercial plasminogens and the proportional differences of activity have been maintained among the three samples, it is very difficult to suppose that the hypofunction of plasminogen in FTN is due to an artifact resulting from purification procedures. Claeys and Vermylen (7) also described how different biologic activities exist between various fractions of purified plasminogen obtained by different authors and different methods of extraction. They suggest that this difference may be due fundamentally to the different techniques used and especially to the possible interference of the EACA that could contaminate the plasminogen sample after the elution of the column (39). It is not possible that the sample was contaminated by EACA because it had been submitted to repeated dialysis until an equilibrium between the phases was obtained. Besides, contamination with traces of plasmin did not occur in the dialysed samples because no plasminic activity was found in them.

Inasmuch as the enzymatic activity of plasminogen is associated with the light chain $(30,35)$ and it is the heavy chain which was retained by the column when the chromatography technique was used for its purification $(28,36)$, another possibility that could explain the hypofunction found in the FTN plasminogen could be that this plasminogen was fundamentally composed of the heavy chain of its molecule. This was not likely to occur because the sample had not been reduced, and besides, the addition of trasylol in the extraction procedure would prevent the plasmin digestion of the plasminogen obtained (14).

Our results suggest the existence of a decrease in functional activity of the FTN plasminogen. We think that this hypofunction could be attributed: (1) to an abnormal FTN plasminogen synthesis; (2) to the conversion of the FTN plasminogen in Lys-plasminogen on Lys-plasmin. It does not seem likely that Lys-plasmin would cause this hypofunction because we have not found any detectable plasmin activity in the unactivated purified plasminogen obtained as measured by chromogenic substrate. If the cause were Lys-plasminogen, this would have to be activated by streptokinase and urokinase with greater rapidity than if it were Gluplasminogen $(6,38,41)$, and thus, this structural anomaly would not lead to the hypofunction which has been found.

It could also be assumed that Lys-plasmin has been generated and that through a process of autolysis it would have hydrolized 


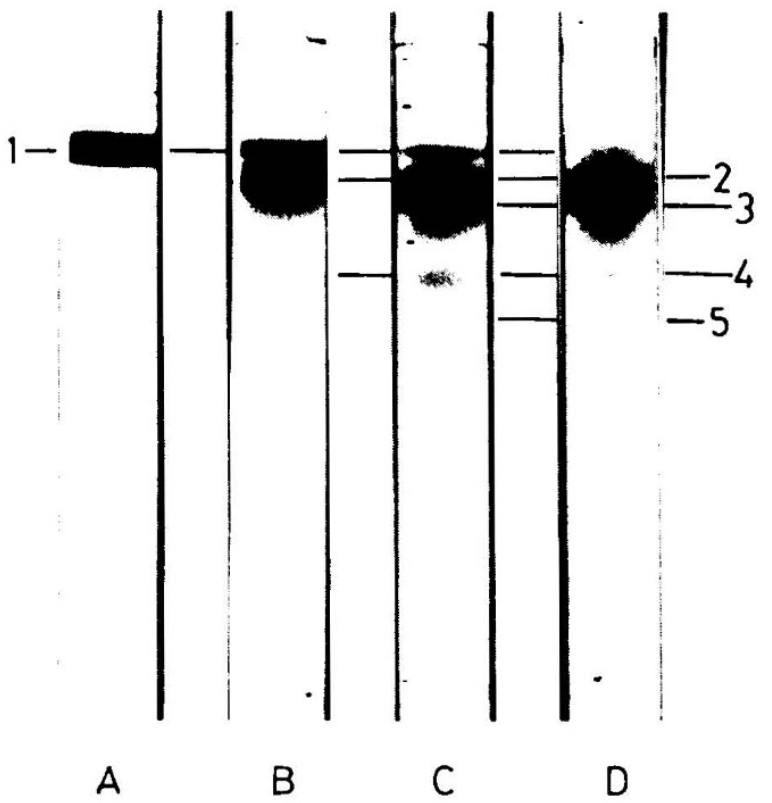

Fig. 4. Electrophoresis in 5\% polyacrylamide gel in presence of $0.1 \%$ SDS of a reduced samples from commercial plasminogen activated with catalytic streptokinase. Digestion time: $A, 0 \mathrm{~min} ; B, 5 \mathrm{~min} ; C, 20 \mathrm{~min} ; D$, $40 \mathrm{~min}$. Bands: $I$, plasminogen (molecular weight, 92,000); 2 , heavy chain (molecular weight, 64,000); 3, degradated heavy chain (molecular weight. 54,000): 4, light chain (molecular weight, about 14,000)

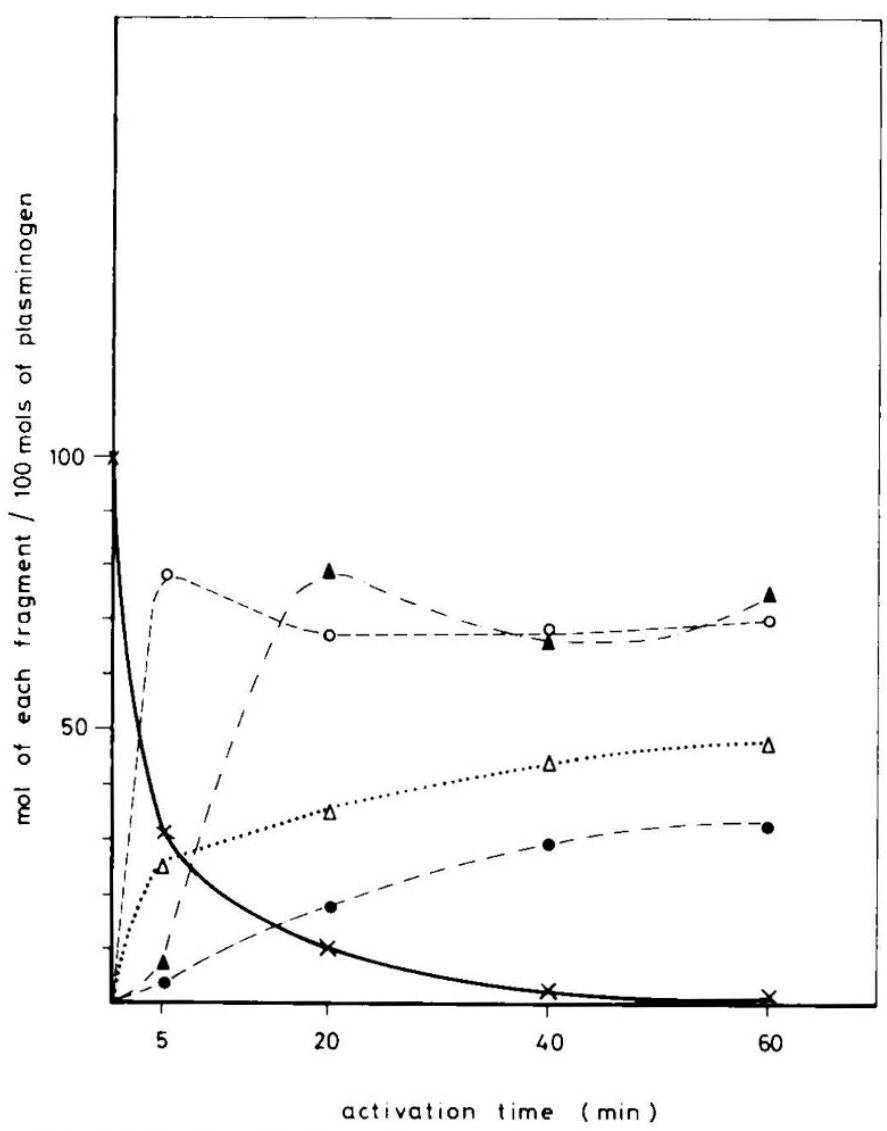

Fig. 5. Kinetic activation with catalytic streptokinase of commercial plasminogen quantitative data obtained by scanning the reduced SDS polyacrylamide gels $\times$, band $1 ; O$, band $2 ; 0$, band $3 ; \Delta$, band $4 ; \Delta$, band 5 of Figure 4.

its light chain as occurs "in vitro" $(14,35)$ with a loss of its functional activity. This inactive plasmin would not be able to be activated by streptokinase nor by urokinase, nor would it give direct plasmin activity. However, this hypothesis does not seem probable because a band of molecular weight similar to that of plasminogen appears predominantly in the reduced FTN plasminogen sample without activation, and only a small proportion of a band with a molecular weight similar to that of the heavy chain of plasmin appears.

On the other hand, the decrease in the residues of amino acids per mole of FTN plasminogen suggests the loss of some peptide (an activation peptide?) which would be confirmed by the different $\mathrm{N}$-terminal amino acid found in both types of plasminogen (valine in FTN plasminogen and glutamic acid in adult plasminogen).

Our experience suggests the possible existence of a functional anomaly in FTN plasminogen.

\section{REFERENCES AND NOTES}

1. Ambrus, C. M.: Ontogeny of fibrinolysin system and its role in pathogenesis of hyaline membrane disease of infants. Fed. Proc., 25: 68 (1966).

2. Ambrus, C. M.. Wintraub, D. H.. Dunphy, D., Eowd, J. E.. Pickren, J. W. Niswander, R. K. and Ambrus, J. L.: Studies of hyaline membrane disease. I. The fibrinolysin system in pathogenesis and therapy. Pediatrics. 32: 10 (1963).

3. Aoki, N., Moroi, M.., Sakata. Y., and Yoshida. N. G.: Abnormal plasminogen. A hereditary molecular abnormality found in a patient with recurrent thrombosis. J. Clin. Invest.. 61: 1186 (1978).

4. Biland. L.. and Duckert. F.: Coagulation factors of the newborn and his mother. Thromb. Diath. Haemorrh., 29: 644 (1973).

5. Burstein, M., Lewi, S., and Walter. P.: Sur l'existence du fibrinogen foetal. Sang. 25: 102 (1954).

6. Claeys, $\mathrm{H}$., and Vermylen, J.: Conversion of $\mathrm{NH}_{2}$-terminal glutamic acid to $\mathrm{NH}_{2}$ terminal lysine human plasminogen by plasmin. Thromb. Res., 3: 515 (1973)

7. Claeys. H., and Vermylen. H.: Physico-chemical and proenzyme properties of $\mathrm{NH}_{2}$-terminal glutamic acid and $\mathrm{NH}_{2}$-terminal lysine human plasminogen. Biochim. Biophys. Acta, 342: 351 (1974).

8. Corby, D. G., and Zuck, T. F.: Newborn platelet dysfunction. Thromb. Haemostasis. 36: 200 (1976).

9. Deutsch, D. G., and Mertz, E. T.: Plasminogen purification from human plasma by affinity chromatography. Science (Wash. D. C.). 170: 1095 (1970).

10. Ekelund. H.. Hedner, U.. and Nilsson, I. M.: Fibrinolysis in newborn. Acta Paediatr. Scand., 59: 33 (1970).

11. Estelles. A., Aznar, J.. Ortega. C., Parrilla, J. J., and Vila, V.: Técnica para la valoración del plasminógeno humano por un método de inhibición de la hemaglutinacion. Sangre (Barc.), 20: 358 (1975)

12. Friberger, P., Knos, M., Gustavsson, S., Aurell. L., and Claeson. G.: Methods for determination of plasmin, antiplasmin and plasminogen by means of substrate S-2251. Haemostasis, 7: 138 (1978).

13. Friberger. P.. and Knos, H.: Plasminogen assay in human plasma (unpublished data)

14. Gaffney, P. J., Braher, M.. Lord, K., and Kirkwood. T. B. L.: Activation of plasminogen as a feature in its assay. Haemostasis, $6: 72$ (1977).

15. Gros, $C_{\text {.. }}$ and Labounesse, B.: Study of the dansylation reaction of amino acids, peptides and proteins. Eur. J. Biochem.. 7: 463 (1969).

16. Hathaway, W. E.: Coagulation problems in the newborn infant. Pediatr. Clin. N. Am.. 17: 929 (1970).

17. Hathaway, W. E.: The bleeding newborn. Clin. Perinatol., 2: 83 (1975).

18. Hawkey. C. M.. and Stafford. J. L.: A standard clot method for assay of plasminogen activators antiactivators and plasmin. J. Clin. Pathol. (Lond.), 17: 175 (1964).

19. Hedner, U.. and Nilsson. I. M.: Determination of plasminogen in human plasma by a casein method. Thromb. Diath. Haemorrh., 14: 545 (1965).

20. Hrodetz. O.: Blood platelets in the newborn, their function in haemostasis and haemocoagulation. Acta. Univ. Carol. Med. Monogr. XXII (1966).

21. Kunzer. W.: Fetales fibrinogen I. Klin. Wochenschr., 39: 536 (1961).

22. McClintock. D. K., Englert, M. E., Dzioblowski. C.. Snedeker. E. H.. and Bell. P. H.: Two distinct pathways of the streptokinase mediated activation of highly purified human plasminogen. Biochemistry. 13: 5334 (1974).

23. Mull. N. M.. and Hataway. W. E.: Altered platelet function in newborn. Pediatr Res., 4: 229 (1970).

24. Nielsen, N. C.: Coagulation of fibrinolysis in prematureiy delivered mothers and their premature infants. Obstet. Gynecol. Scand., 48: 505 (1970).

25. Ouchterlony, O.: Diffusion-in-gel methods for immunological analysis. Prog. Allergy, 5: 11 (1958).

26. Potron, G.. Leroux, B.. Bertignon. C.. and Graftiaux. A.: Variations du plasminogene chez le nouveau-ne et le premature. Arch. Fr. Pediatr., 29:583 (1972).

27. Quie. P. G.. and Wahnamaker, L. W.: The plasminogen-plasmin system of newborn infants. Am. J. Dis. Child.. 1(0): 836 (1960).

28. Rickli. E.. and Otavski, l.: A new method of isolation and some properties of the heavy chain of human plasmin. Eur. J. Biochem.. 59: 441 (1975).

29. Robbins. K. C.. Boreisha. I. G.. Arzadon, L., and Summaria. L.: Physical and chemical properties of $\mathrm{NH}_{2}$-terminal glutamic acid and lysine forms of human plasminogen and their derived plasmin with $\mathrm{NH}_{2}$-terminal lysine Heavy (A) chain. J. Biol. Chem.. 250: 4044 (1975).

30. Robbins. K. C., and Summaria. L.: Human plasminogen and plasmin. Methods Enzymol., 19: 184 (1970).

31. Robbins. K. C.. and Summaria, L.: Plasminogen and plasmin. Methods Enzymol., 45: 257 (1976).

32. Schettini, F.. de Mattia, D., and Mautone, A.: Preprothrombin and prothrombin in fullterm newborns. Haemostasis, 1: 271 (1972-73). 
33. Schettini, F., de Mattia, D., Mautone, A., and Altomare, M.: Post-Natal development of Factor II (pre-prothrombin and prothrombin) in man. Biol. Neonate. 29: 82 (1976).

34. Shapiro, A. L.. Viñuelas, E.. Maizez, J. V.: Molecular weight estimation of polypeptide chains by electrophoresis in SDS polyacrylamide gel. Biochem Biophys. Res. Commun., 28: 815 (1967).

35. Summaria, L., Hsieh, B., Gros Kopf, W. R.. Robbins, K. C.. and Barlow, G. H The isolation and characterization of the S-carboxymethyl (light) chain derivative of human plasmin. The localization of the active site of the (light) chain. J. Biol. Chem., 242: 5046 (1967).

36. Summaria. L., and Robbins. K. C.: Isolation of a human plasmin-derived. functionally active Light (B) chain capable of forming with streptokinase an equimolar Light (B) chain streptokinas complex with plasminogen activator activity. J. Biol. Chem., 251: 3693 (1976).

37. Teger-Nilsson, A. C.. Friberger, P., and Gyzander, E.: Determination of a new plasmin inhibitor in human blood means of a plasmin specific tripeptide substrate. Scand. J. Clin. Lab. Invest., 37: 403 (1977).

38. Ts'ao, Ch., Green, D., and Schultz, K.: Function and ultrastructure of platelets of neonates. Enhanced ristocetin aggregation of neonatal platelets. Br. J. Haematol.. 32: 225 (1976).

Copyright (1) 1980 International Pediatric Research Foundation, Inc. $0031-3998 / 80 / 1411-1180 \$ 02.00 / 0$
39. Walther, P. J., Hill. R. L.. McKee, P. A.: The importance of the preactivation peptide in the two-stage mechanism of human plasminogen activation. J. E1ol. Chem., 250: 5926 (1975).

40. Whaun, J. M.: The platelet of the newborn infant. 5-Hydroxytryptamine uptake and release. Thromb. Diath. Haemorrh., 30: 327 (1973)

41. Wiman, B., and Wallen, P.: Activation of human plasminogen by an insoluble derivative of urokinase. Eur. J. Biochem.. 36: 25 (1973).

42. Witt. I., Muller, H., and Funzer, W.: Evidence for the existence of foetal fibrinogen. Thromb. Diath. Hemorrh.. 22: 101 (1969).

43. Wu, K. K., Jacohsen, C. D., and Hoak. J. C.: Highly sensitive method for the assay of plasminogen. J. Lab. Clin. Med., 81: 484 (1973).

44. Zolton, R. P., and Mertz. E. T.: Assay of human plasminogen in plasma by affinity chromatography. Clin. (hem., 18: 655 (1977).

45. The authors wish to thank Miss Pilar Escamilla and Miss Araceli Serralbo for their technical assistance given during the realization of this study.

46. Requests for reprints should be addressed to: Dr. J. Aznar. Departamento de Biopatologia Clinica, Ciudad Sanitaria "La Fe". Valencia. Spain.

47. Received for publication September 26. 1979.

48. Accepted for publication March 3. 1980. 